Acta Bot. Croat. $72(1), 97-111,2013$

CODEN: ABCRA 25

ISSN 0365-0588

eISSN $1847-8476$

DOI: $10.2478 / \mathrm{v} 10184-012-0008-6$

\title{
Population structure of woody plants in the arid cloud forests of Dhofar, southern Oman
}

\author{
MOHAMEd A. El-SHEIKH*,** \\ Department of Botany, Faculty of Science, Damanhour University, Damanhour, Egypt
}

\begin{abstract}
This study evaluates the size frequency distribution of 11 trees and shrubs in the cloud forest in Wadi Garziz, southern Oman, in order to assess their current situation, which is affected by cutting, overgrazing and other constraints. A size class distribution and a vegetation structure analysis were applied in order to analyze the dynamics of this forest using census data from 51 plots selected across 5 transects covering the hill-slope and wadi-bed habitats. Some of the trees inhabiting the hill-slopes (e.g. Acacia senegal and Commiphora spp.) were found to exhibit an inverse J-shaped distribution with constant regeneration, whilst in the wadi bed these same trees exhibited a J-shaped distribution (i.e. of declining populations). On the other hand, Acacia etbaica inhabiting the hill-slopes exhibited a tendency towards a J-shaped distribution and an inverse J-shaped distribution in the wadi-bed. All the populations (i.e. inhabiting the hill-slopes and the beds) of Anogeissus dhofarica had a J-shaped distribution whereas all the populations of Blepharispermum hirtum had a more or less inverse J-shaped distribution. The Ziziphus spina-christi and Acacia tortilis populations, meanwhile, exhibited the bi-modal shape of size distribution. The shrubs inhabiting the hill-slopes (e.g. Coroton confertus and Ormocarpum dhofarense) exhibited a tendency towards a J-shaped distribution; such distribution characterizes a declining population with a limited regenerational capacity. Overall, most of the examined populations, except those of Acacia etbaica in wadi-bed and Blepharispermum hirtum, seemed to be under stress from both environmental and human factors, particularly in the wadi bed. This type of study can provide a basis for the development of a management plan to support the conservation and sustainable use of forest vegetation in an arid region.
\end{abstract}

Key words: Cloud forest, distribution of trees, ecosystem management, seed dispersal

\section{Introduction}

Oman is situated in the latitudinal belt of subtropical deserts of the Northern Hemisphere. Water is generally considered to be the most important limiting factor for the

* Corresponding address, e-mail: el_sheikh_eg@yahoo.co.uk

**Present address: Botany and Microbiology Department, College of Science, King Saud University, P. O. Box 2455, Riyadh 11451, Saudi Arabia

Copyright ${ }^{\circledR} 2013$ by Acta Botanica Croatica, the Faculty of Science, University of Zagreb. All rights reserved. 
germination, growth and productivity of woody plants in desert ecosystems like those of Oman (BAXTER et al. 2005, ShALTOuT et al. 2009). In the forests of northern Oman, for example, FISHER and GRANDER (1995) have identified variations in the population size and regeneration of juniper woodlands as being affected by the microclimate, topography and hydrology of the area. In addition to these environmental and climatological factors, however, human activities (primarily over-grazing by livestock and related disturbances) are one of the principal influences on woodland species (OLIVER 1980, AGREN and ZACHRisson 1990, Skarpe 1990, Stewart and Rose 1990, Welden et al. 1991, Veblen 1992, SAKIO 1997, LYKKE 1998, SAKIO et al. 2002, TANAKA et al. 2008).

Even within desert regions, there may be significant local variations in water limitation. In cloud forests, for example, cloud condensation in fog-affected escarpment mountain slopes and fog precipitation during the summer season create a niche for moist woodland vegetation within the surrounding desert. In a cloud forest, woodland vegetation is able to gain enough water for survival through enhanced capture (filtering) of cloud water by tree canopies or from horizontal precipitation. This is the case in parts of the Dhofar Mountains of Oman, which are a remnant of a much more extensive moist vegetation belt, which once spread across the Arabian Peninsula (RADCLIFFE-SMith 1980).

The cloud forest of the Dhofar Mountains is classified as a centre of plant diversity in the Arabian Peninsula, with approximately 750 species, of which some 60 are endemic (RADCLIFFE-SMith 1980, MilleR 1994). Dhofar, like other areas of Oman, is developing rapidly, and this development has the potential to put the ecosystem under stress through increased human activities, such as cutting for firewood, housing, road building, and also from overgrazing. One of the features of a cloud forest is that a large proportion of total precipitation is filtered by the very presence of vegetation. Once vegetation is degraded, therefore, it becomes more difficult to re-establish due to the reduced level of filtered precipitation. Over-use of the Dhofar cloud forest has the potential, therefore, to seriously threaten this diverse ecosystem (Miller and Morris 1988, GHAZANFAR 1998).

Throughout Dhofar an urgent need exists for conservation measures and the adoption of sustainable utilization methods for keystone tree species, so that further degradation of natural resources can be avoided. This is especially the case since trees and shrubs can be of high ecological, economic and medicinal importance in arid regions (MILLER and MoRRIS 1988, ShEDED et al. 2006, BRigGs et al. 2007, ShAltout et al. 2009). Efficient management plans, however, must be based on knowledge of the current situation and the trends towards change in that situation.

The present work assessed the actual status of tree and shrub populations in the Dhofar cloud forests on the basis of static vegetation data. For this, the size structure of 11 populations of trees and shrubs in Wadi Garziz, southern Oman, were analyzed. Based on this analysis, factors affecting the survival of individuals in each population were identified and the regeneration, stability and decline status of these populations were described. The paper uses size-class distribution to consider the nature of the population changes in severely disturbed sites in the cloud forest and seeks to identify causes of population stress in order to inform subsequent population management plans.

The structure of a population of plants may be described in terms of the age and size of the population, and the form of its life stages. Since the fecundity and survival of plants are much more closely related to size than age (HARPER and WHITE 1974, HARPER 1977, WEINER 1986), some authors, e.g. (Werner and CASSwell 1977, CASSWEll 1986, Shaltout and 
Ayyad 1988, Shaltout et al. 2009) have argued that it is preferable to classify the life history of a plant by size rather than by age. Size-class distribution of trees has traditionally been employed in studies of forests specifically as an indicator of changes in species composition (ANonymous 1983, Newbery and Gartlan 1996, PoORTER et al. 1996, LyKKe 1998). A reverse J-shaped size-class distribution curve is usually characteristic of a species with good regeneration and continuous replacement, whereas distribution curves deviating from such a reverse-J shape tend to indicate a lack of recruitment and may indicate changes in species composition (HALL and BAWA 1993, LYKKE 1998).

Like all ecosystems, forests undergo changes brought about by a combination of endogenous and exogenous processes (RICHARD and DANIEL 2004). The population size structure of a woody species reflects regeneration processes and, when compared with the spatial structure of the forest, can reveal important insights regarding forest dynamics (TAKAHASH et al. 2001, Hou et al. 2004).

\section{Study area}

The study area is Wadi Garziz, $17^{\circ} 07^{\prime} 55^{\prime \prime} \mathrm{N}, 54^{\circ} 01^{\prime} 59^{\prime \prime} \mathrm{E}$, which is a part of the Dhofar region, southwest Oman. Along the southern coast, there is a range of limestone mountains covered by a woody vegetation type unique in Arabia (MILLER and MORRIS 1988). The mountains extend eastwards from the Yemen border as a crescent-shaped escarpment with a length of about $290 \mathrm{~km}$ (Fig. 1). The top of the range consists of a rolling plateau rising to over $2100 \mathrm{~m}$, dissected by deep wadis (EL-BAz 2002). There are no permanent water-courses, but pools persist in the wadi beds and a series of spring-fed pools can be found along the foot of the mountains. From June to mid-September the south-facing escarpments

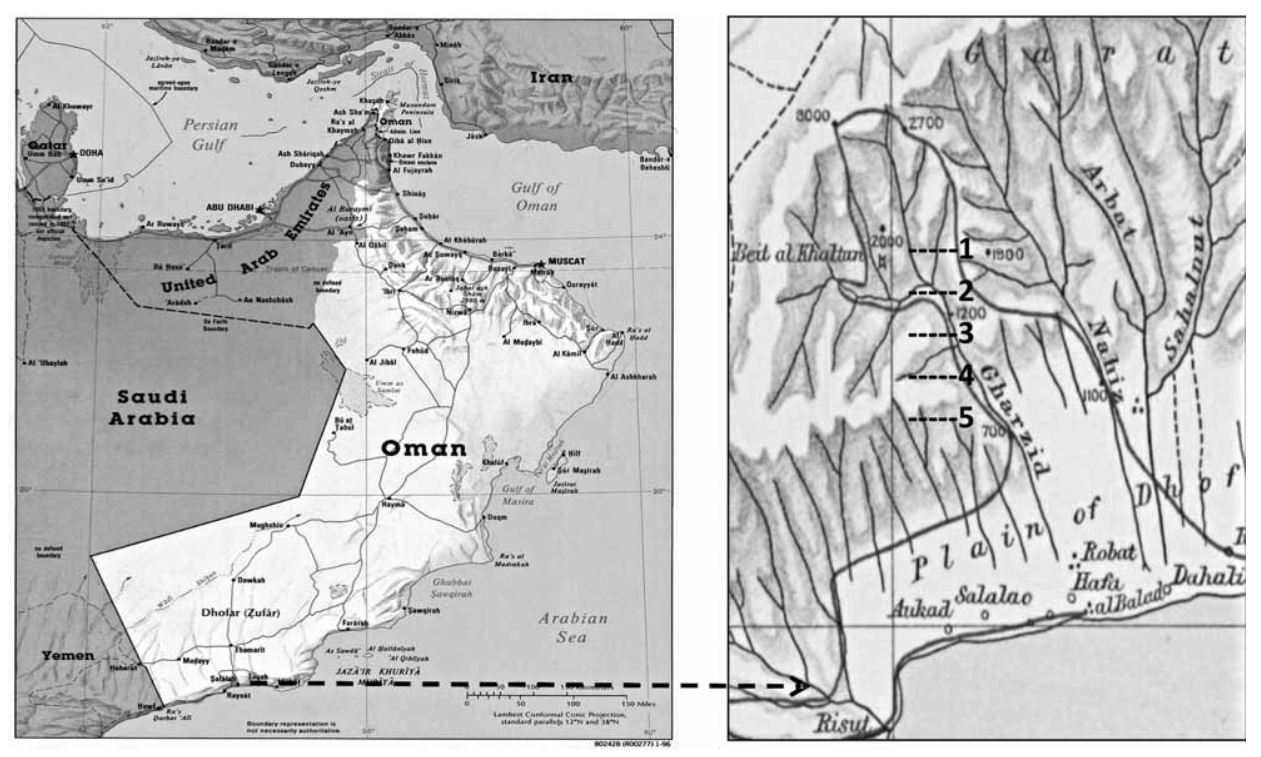

Fig. 1. Map of Oman showing the study area of Wadi Garziz (a), and a topographical map showing wadi Garziz and a part of plain of Dhofar with 5 transects (b). 
are blanketed by moisture-laden clouds, fed by southwest monsoon weather patterns (Fig. 2). Due to this, the region hosts a unique seasonally water-limited cloud forest, sustained by water droplets from the foggy clouds that condense on the plant surfaces and thence supply water to the soil. During the dry season, the trees can take up the required water from the supplemental water reserves percolated down to the ground water (RADCLIFFE-SMITH 1980, Miller and Morris 1988, HildebrandT and Eltahir 2006).

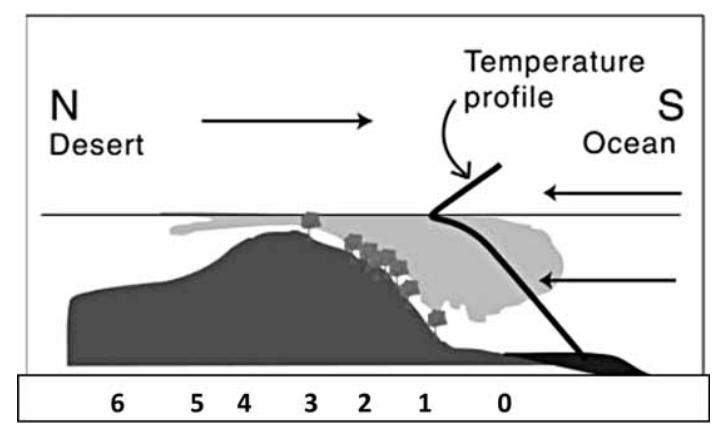

Fig. 2. Meteorological situation in Dhofar during the monsoon, and a diagrammatic representation of a section through Dhofar showing the main habitats from sea to desert: 0 - ocean, 1 coastal, 2 - foothills, 3 - escarpment, 4 - dry plateau, 5 - north cliffs, 6 - desert (modified from HILDEBRANDT et al. 2007).

Meteorological data for the region from the period 1942-1972 (SALE 1980) indicate that mean temperatures at the coastal plain of Salalah reach a high of $32{ }^{\circ} \mathrm{C}$ in May and June, and a low of $27^{\circ} \mathrm{C}$ in January and February. The highest relative humidity (97\%) is in July and August during the period of monsoon currents, and the lowest (40\%) is in February. Unfortunately no data from continuous measurements are available for the mountains. However, at 'Qayrun Heriti' village, near the mountain, the total rainfall during the monsoon season is more than $200 \mathrm{~mm}$ in June, July and August (Fig. 3) (ANONYMOus 2004). The soil of the wadi beds is alluvial with fine particles (EL-BAZ 2002).

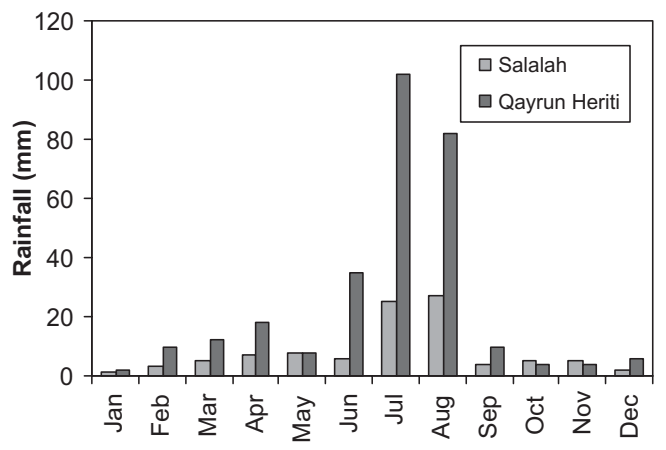

Fig. 3. Mean rainfall (in mm) in Salalah (elevation: $25 \mathrm{~m}$ ) and the mountain village 'Qayrun Heriti' (elevation: $880 \mathrm{~m}$ a.s.1.). 


\section{Materials and methods}

A field survey was carried out in the western slope (600-1200 $\mathrm{m}$ a.s.1.) and the wadi-bed (500-600 m a.s.1.) of Wadi Garziz. The study was carried out during winter in 2007 after the monsoon season. Five W-E transects were established in the study area (Fig. 1a and b) and 51 plots of $20 \times 20 \mathrm{~m}$ size were selected ( 27 plots on the hill-slope and 24 on wadi-bed) with the variation in the number of plots depending on the habitat heterogeneity. In each plot eleven taxa of trees and shrubs of the cloud forest were sampled (Tab. 1). These species were selected as they are the most common species, they are native and endemic woody species and constitute the main body of the forest, which is under severe anthropogenic disturbances. These species were identified according to MILLER and MoRRIS (1988) and

Tab. 1. Characteristics of the sampled species in Wadi Gerziz, Oman showing their families and dispersal type. Endemic species according to (MILLER and MORRIS 1988) are in bold.

\begin{tabular}{|c|c|c|}
\hline Species & Family & Dispersal type \\
\hline \multicolumn{3}{|l|}{ TREES } \\
\hline Acacia tortilis (Forssk.) Hayne & Fabaceae & Fruit legume, Seed 6 mm 'Ballochore' \\
\hline Acacia etbaica Schweinf. & Fabaceae & Fruit legume, Seed 6 mm 'Ballochore' \\
\hline Acacia senegal Willd. & Fabaceae & Fruit legume, Seed 6 mm 'Ballochore' \\
\hline Anogeissus dhofarica A. J. Scott & Combretaceae & Two winged 'Pterochore' \\
\hline Blepharispermum hirtum Oliv. & Asteraceae & With pappus and bristle 'Pogonochore' \\
\hline Commiphora habessinica (Berg.) Engl. & Burseraceae & Drupe 9 mm 'Sarcochore' \\
\hline Commiphora gileadensis (L.) C. Christ & Burseraceae & Drupe 8 mm 'Sarcochore' \\
\hline Ziziphus spina-christi (L.) Willd. & Rhamnaceae & Drupe $1 \mathrm{~cm}$, Seed 5 mm 'Sarcochore' \\
\hline \multicolumn{3}{|l|}{ SHRUBS } \\
\hline Croton confertus Baker & Euphorbiaceae & Capsule with hairs, seed $7 \mathrm{~mm}$ 'Desmochore' \\
\hline Ormocarpum dhofarense Hillcoat et Gillett & Fabaceae & Legume 'Ballochore' \\
\hline Sideroxylon mascatense (Falc.) A. DC. & Sapotaceae & Berry 15 mm 'Sarcochore' \\
\hline
\end{tabular}

include eight trees (Acacia tortilis, Acacia etbaica, Acacia senegal, Anogeissus dhofarica, Commiphora habessinica, Commiphora gileadensis, Blepharispermum hirtum and Ziziphus spina-christi) and three shrubs (Croton confertus, Ormocarpum dhofarense and Sideroxylon mascatense). Seed and fruit dispersal types were described according to the scheme of DANSEREAU and LEMS (1957), which distinguishes dispersal types primarily according to the morphology of the diaspore. The seed dispersal types recognized in the present study are: ballochore: parent plant with a mechanism for diaspore expulsion; sarcochore: diaspore with juicy or fleshy outer layer; pterochore: diaspore with scarious winglike appendages; desmochore: diaspore with short, stiff or hooked appendages; and pogonochore: with long hair-like appendages. The species dispersal frequency was calculated in each plot; the ratio between the number of individuals of the species and number of individuals of all species of dispersal types in the habitat. Impacts of human activities such as cutting, firing, grazing and resultant gaps were recorded in each plot.

In the concerned plot, the height $(\mathrm{H})$ and mean crown diameter (CD: based on three crown diameters depending on the uniformity of the measured individual) of each indi- 
vidual belonging a certain species were measured $(\mathrm{cm})$. Species size index was calculated as: H+CD)/2 (modified from CRISP and LANGE 1976, by ShalTout et al. 2003). The size index values of each species were used to determine the frequency distribution of the different age (size) cohorts. In order to evaluate the characteristics of each size class, the total density of the plant species per ha was also calculated. Mean and coefficient of variation of density, height, crown diameter and size index of each species were calculated.

\section{Results}

\section{Vegetation structure}

In the vegetation of Wadi Garziz, Acacia species represented the greatest proportion of the dominant family Fabaceae, followed by Burseraceae species (Tab. 1). Concerning seed and fruit dispersals, pogonochore (e.g. Blepharispermum hirtum) species, which depend on wind dispersal, attained the highest individual density in the study area, followed by sarcochorous species that usually depend on dispersal by animals (Fig. 4). Because of the human impact, the cloud forest is a disturbed environment, the wadi-bed more so than the hill-slope (Fig. 5).

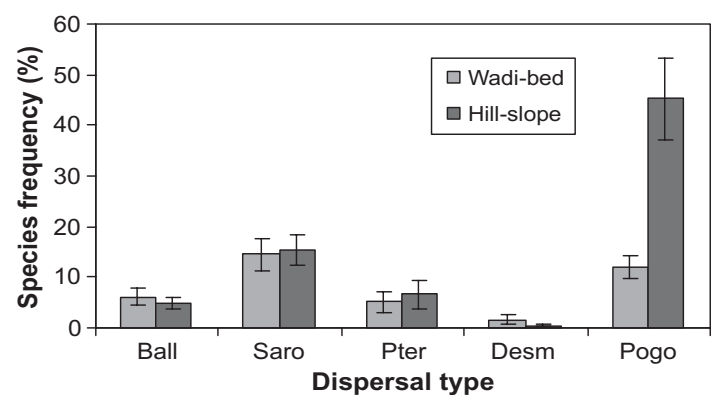

Fig. 4. The relative species dispersal frequency in the two habitats of cloud forests. Ball - Ballochore, Saro - Sarochore, Pter - Pterochore, Desm - Desmochore, Pogo - Pogonochore.

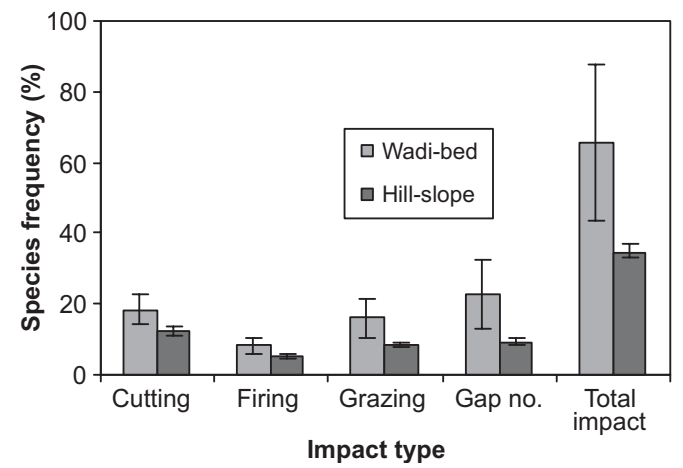

Fig. 5. Frequency of the human impact types (\%) in the two habitats of cloud forests. 
Acacia etbaica exhibited twice as many individuals per hectare in the wadi-bed area (105 individuals $\mathrm{ha}^{-1}$ ) as on the hill-slopes (53 individuals $\mathrm{ha}^{-1}$ ). On the other hand, the density of most other taxa was distinctly higher on the slope plots. Sometimes, they were exclusively present on slope plots. The trees Acacia tortilis and Ziziphus spina-christi, however, exhibited almost the same density of individuals at the hill-slope and the wadi-bed sites (Tab. 2). The highest density of occurrence (398 ind./ha) was found in the Blepharispermum hirtum population, followed by that of Commiphora gileadensis established on the hill-slope, while the population of Ormocarpum dhofarense showed the lowest density (67 individuals $\mathrm{ha}^{-1}$ ), being found exclusively on the hill-slopes. The height of most tree species exceeded five metres. In most cases relationships between the individual crown diameter and the height of the 11 studied species are simple linear with $\mathrm{r}$ values $>0.7$ except for »Sideroxylon mascatense and Ormocarpum dhofarense«. The mean height/crown diameter ratio is $>1.0$ for all species (Tab. 2)

Tab. 2. Mean values of some demographic variables of the common shrubs and trees in Wadi Gerziz, Oman. B: Wadi-bed, S: Wadi slope, H: Height and CD: Crown Diameter.

\begin{tabular}{|c|c|c|c|c|c|c|c|}
\hline \multirow{2}{*}{ Species } & \multicolumn{2}{|c|}{$\begin{array}{c}\text { Density } \\
\left(\text { ind }^{-1}{ }^{-1} \text { ) }\right.\end{array}$} & \multirow{2}{*}{$\begin{array}{l}\text { Height } \\
(\mathrm{cm})\end{array}$} & \multirow{2}{*}{$\begin{array}{l}\text { Crown } \\
\text { diameter } \\
(\mathrm{cm})\end{array}$} & \multirow{2}{*}{$\mathrm{H}: \mathrm{CD}$} & \multirow{2}{*}{$\begin{array}{c}\text { Size class } \\
\text { index } \\
(\mathrm{cm})\end{array}$} & \multirow{2}{*}{$\begin{array}{c}\text { r-value } \\
\text { between } \\
\mathrm{H} \text { and CD }\end{array}$} \\
\hline & $\mathrm{S}$ & $\mathrm{B}$ & & & & & \\
\hline \multicolumn{8}{|l|}{ Trees } \\
\hline Acacia tortilis & 117 & 106 & 538 & 341 & 1.57 & 440 & 0.89 \\
\hline Acacia etbaica & 53 & 105 & 413 & 281 & 1.47 & 348 & 0.92 \\
\hline Acacia senegal & 303 & 116 & 522 & 376 & 1.38 & 450 & 0.86 \\
\hline Anogeissus dhofarica & 194 & 139 & 680 & 462 & 1.47 & 572 & 0.79 \\
\hline Blepharispermum hirtum & 398 & 170 & 296 & 163 & 1.81 & 230 & 0.88 \\
\hline Commiphora habessinica & 130 & 35 & 154 & 100 & 1.53 & 127 & 0.89 \\
\hline Commiphora gileadensis & 311 & - & 72 & 18 & 3.90 & 45 & 0.97 \\
\hline Ziziphus spina-christi & 147 & 133 & 568 & 396 & 1.43 & 482 & 0.88 \\
\hline \multicolumn{8}{|l|}{ Shrubs } \\
\hline Croton confertus & 258 & - & 592 & 393 & 1.50 & 493 & 0.82 \\
\hline Ormocarpum dhofarense & 67 & - & 210 & 179 & 1.17 & 195 & 0.69 \\
\hline Sideroxylon mascatense & 215 & - & 145 & 75 & 1.94 & 110 & 0.27 \\
\hline
\end{tabular}

\section{Population size classes frequency distribution}

The size class frequency distribution of some trees inhabiting the hill-slopes (e.g. Acacia senegal and Commiphora spp.) showed an inverse J-shaped distribution, while they attained a J-shaped distribution in the wadi-bed populations (Fig. 6). On the other hand, Acacia etbaica inhabiting the hill-slopes demonstrated a J-shaped distribution, while in the wadi-bed it showed an inverse J-shaped distribution. The entire populations (i.e. inhabiting both of the hill-slopes and wadi-beds) of Anogeissus dhofarica attained a J-shaped distribution, whereas all the populations of Blepharispermum hirtum had more or less an inverse J-shaped or positively skewed size frequency distribution. Meanwhile, all the populations of Ziziphus spina-christi and Acacia tortilis exhibited a bi-modal shaped size frequency distribution. 


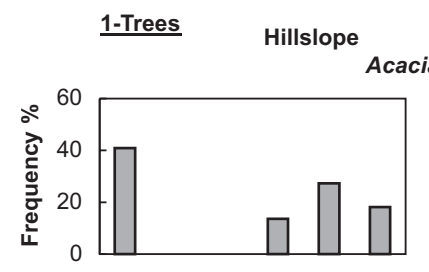

Bed

1-Trees

Hillslope

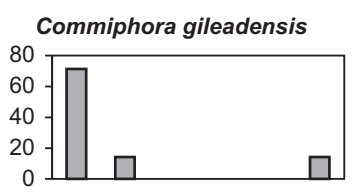

2-Shrubs
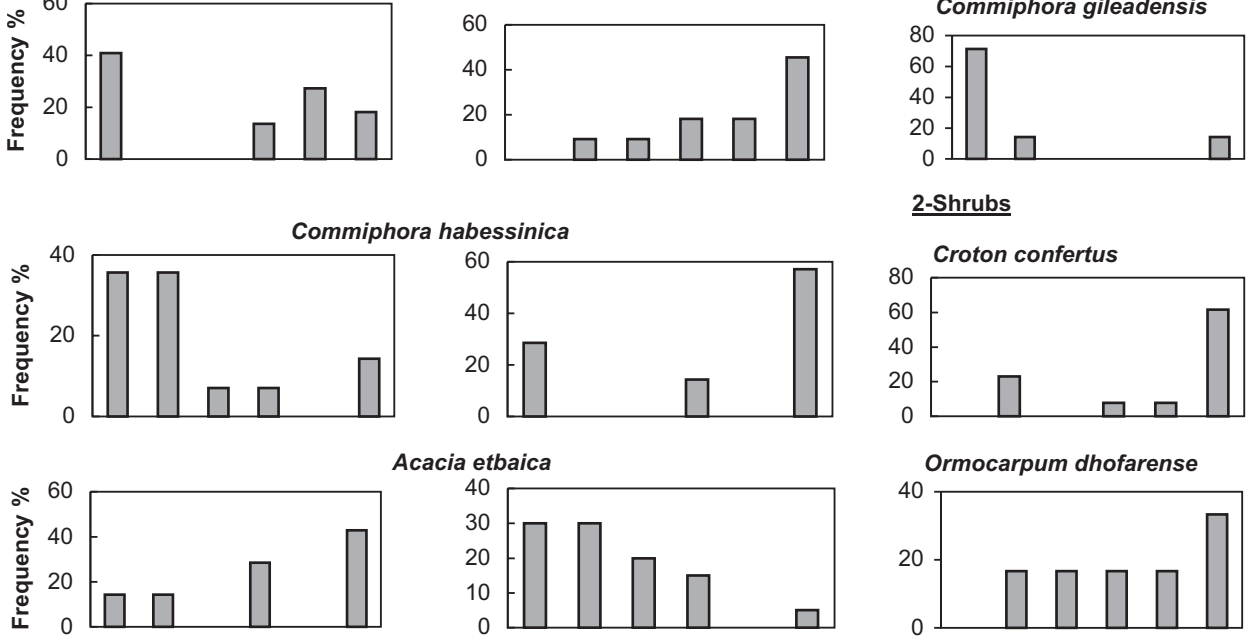

Acacia etbaica
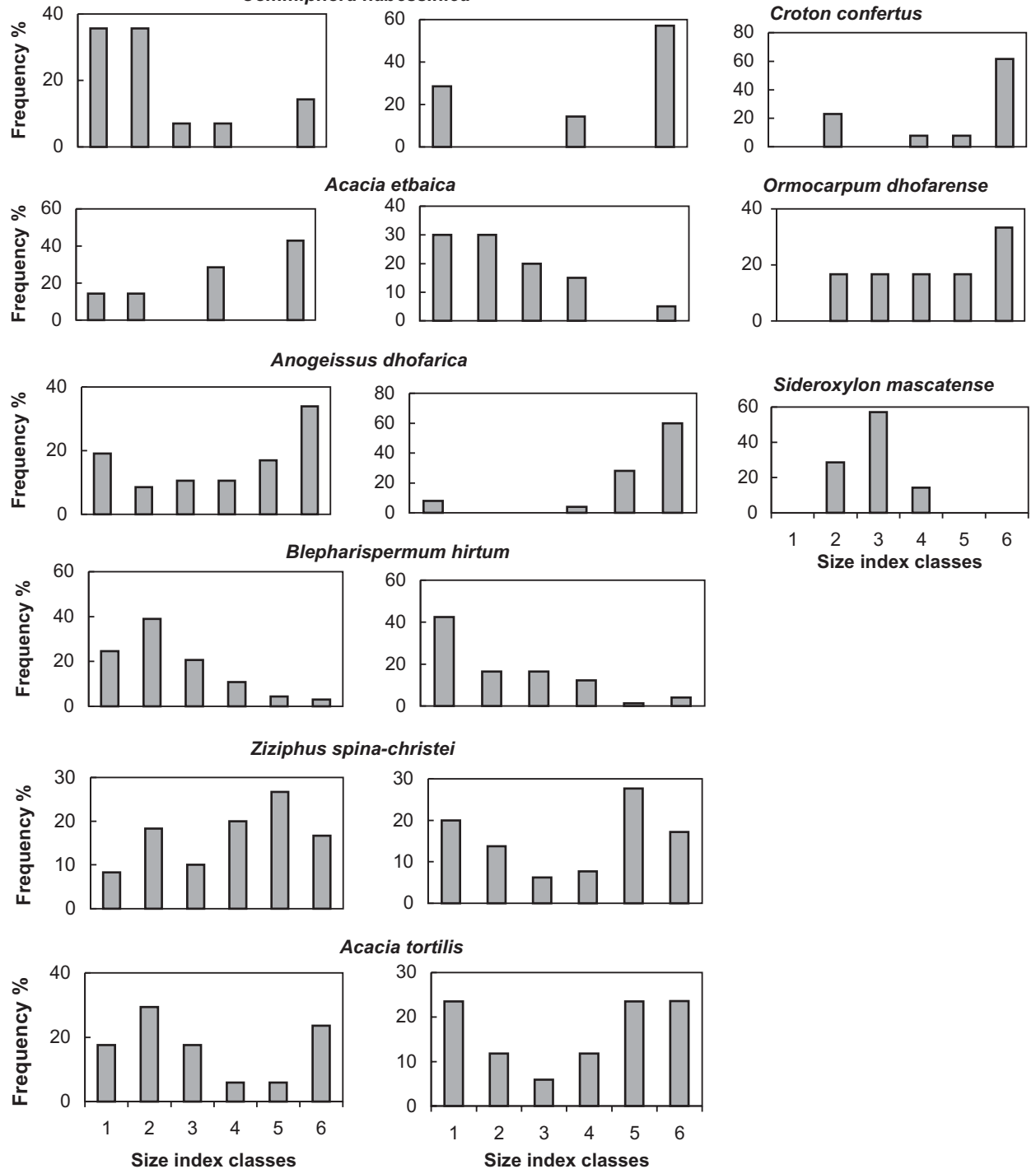

Acacia tortilis

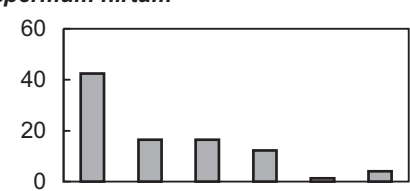

Size index classes

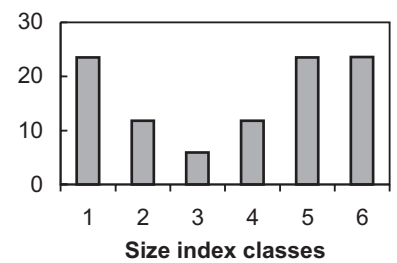

Fig. 6. Size-frequency distribution of the 11 common woody populations in the Dhofar region of Oman. The ranges of size index classes are as follows: for 8 trees are $1=<100,2=100-250$, $3=250-400,4=400-550,5=550-700$ and $6=>700$. For the 3 shrubs are $1=<50,2=50-100$, $3=100-150,4=150-200,5=200-250$, and $6=>250 \mathrm{~cm}$. 
The shrubs inhabiting the hill-slopes (e.g. Coroton confertus and Ormocarpum dhofarense) have a tendency towards the J-shaped distribution while Sideroxylon mascatense population showed a bell-shaped distribution. (Fig. 5).

\section{Discussion}

The size differences in plant populations revealed in this study may be caused directly or through differences in growth rates due to age differences, genetic variation, heterogeneity of resources, competition and herbivory (WEINER 1985). As reported by GRAY (1975), the topography and relative abundance of plants with a dense crown, along with the frequency and abundance of rainfall and human impacts are among the important variables to be accounted for in an attempt to quantify the capacity of species for regeneration. Human impact in forest environments frequently leads to vegetation changes that take place faster than natural vegetation transformations, as human impact-caused disturbances often occur in the form of continuous and widespread stress, e.g. cutting, frequent fires, grazing, and construction of roads and buildings. In environments where population changes are significant, the impact of population change on vegetation structure might override other demographic parameters (LYKKE 1998). This discussion will consider the significance of the population changes in the species surveyed in this study.

Populations of Acacia senegal, Commiphora spp. and Blepharispermum hirtum showed a greater density with a size distribution positively skewed or an inverse J-shaped size distribution towards the smaller individuals on the hill-slope as compared to the wadi-bed. The pattern of distribution of these species may represent rapidly growing populations with high reproductive capacity. While such distributions would tend to suggest a high level of juvenile mortality (HARPER 1977, EL-SHEIKH 2005), this does not contra-indicate long-term population stability, since in most stable populations one would expect excess juveniles over mature individuals (CRISP and LANGE 1976, GOLDBERG and TURNER 1986, SHALTOUT and AYYAD 1988, EL-SHEIKH 2005).

If human activities increase in the hill-slope areas, however, small individuals will inevitably die before maturity (LYKKE 1998). This is well demonstrated by the Commiphora spp., for example, which occurred in greater densities on the hill-slope than in the wadi-bed. Whereas the steeper and less accessible hill-slopes tended to exhibit fewer signs of human activity, Commiphora spp. in the wadi-bed appeared subject to over-cutting by natives on account of its aromatic secretions, which are used in folk medicine (BATANOUNY 1987, MiLLER 1994).

A further advantage provided by the steep hill-slopes was that the tree crowns were generally arranged in a step-like fashion and tended to be asymmetrical. This imbricate arrangement allowed more sunlight to penetrate from all sides and enabled individual densities to increase through creating different microhabitats and therefore greater heterogeneity in the substrate (WEISSENHOFER 2005).

Turning now to the endemic shrub Ormocarpum dhofarense, this species demonstrated a lower density and a J-shaped size distribution on the hill-slopes and disappeared totally from wadi-bed. The Ormocarpum dhofarense shrubs were particularly vulnerable to human impact in the wadi-bed, e.g. through overgrazing due to the palatability of this plant, its 
edible fruits, and cutting for folk medicine, firing and construction materials. Moreover, on the hill-slopes, the presence of tall trees represented a limiting factor for the shrubs with a negative influence on individual density. Therefore, overall, Ormocarpum dhofarense was found to be suffering from poor regeneration and insufficient seed dispersal »ballochorous « (WEISSENHOFER 2005).

Among the regional endemic species Blepharispermum hirtum had the highest density in the study area with an inverse J-shaped distribution. This may be because it has minute pogonochores for seed dispersal that allow dispersal by wind distribution. Consequently the seeds of the plant are able to invade large areas, including those less used by human inhabitants. This suggests that micro-environmental sites are suitable for their establishment, growth and survival (GRIME 1979; GREEN and JOHNSON 1996; WANG et al. 1999, 2000; MANABE et al. 2000; Hou, et al. 2004; El-SHEIKH 2005).

On the other hand, only Acacia etbaica, had a wide range of occurrence positively skewed towards small individuals in the wadi-bed rather than the hill-slope. This plant has a higher water demand than other Acacia spp. It tends to proliferate in open environments such as hillsides and the mouths of wadi openings (delta) with deep alluvial soils that receive seasonal flood waters (BATANOUNY 1987, MiLLER 1994, FETENE 2003). Wadi mouths store a significant amount of shallow groundwater where seepage of moisture and runoff collect from the hill-slopes (Miller and Morris 1988, HildEBRANDT and ElTAHIR 2006). Moreover, the ground surface of this habitat is covered with conglomerates and boulders which decrease evaporation and provide shelter for saplings. Acacia etbaica also has a hard stem nature to encroacher overgrazing and has a capacity to recover these degraded sites following enclosures of a few years (FETENE 2003). Field observation confirmed that this plant is able to regenerate following significant disturbance, such as cutting and overgrazing - events which also lead to a clumped distribution of young trees around older mother trees, as well as re-sprouting from dormant stems. Overall, Acacia etbaica ability for vigorous regeneration is a strategy well adapted to the environmental disturbance which is common in the contemporary cloud forest.

The entire population of Acacia tortilis and Ziziphus spina-christi had the same density and bi-modal bell shaped size distribution, which tends to indicate a comparable proportion of juvenile and mature individuals. If the current situation continues, however, the bimodal size distribution would tend to predict a reduction in the population size of this species in the future (Shaltout and Mady 1993, Al-SodAny 2003, El-SheikH 2005). This distribution might have resulted from an initially unimodal size distribution with a discontinuous variation in exponential growth rates among individuals. Sources of discontinuous variation may be due to environmental heterogeneity, gaps, variations in pedo-topography, altitude, impact gradients, undulation, light and soil conditions. It is known that the size structure of some species decreases with increasing undulation and decreasing soil depth (TAKAHASHI 1994, Pelissier and Goreaud 2001, Nishimura and Kohyama 2002). In addition, fluctuation in the availability of water from the short, wet, monsoon season to the long dry season may cause a variable input of new seedlings to the population each year (SHALTOUT and AYYAD 1988). Regarding the gaps, once vegetation is degraded, it becomes more difficult to re-establish due to a reduced level of filtered precipitation by trees, which creates an unbalance in the availability of water (HUSTON 1986, GHAZANFAR 1998, MASAKI et al. 1992, 
TANAKA et al. 2008). Moreover, mature trees change the conditions within their own microsite, which affects the establishment of the same or other species (WILSON and AGNEW 1992) and thus the distribution of saplings is spatially associated with canopy crowns (either conspecific or heterospecific). Some sapling distributions overlap mature trees of the other species along complex environmental gradients (STOHLGREN et al. 1998).

The dominance of Acacia species (as opposed to open canopy species) in the Dhofar forests is reflective of their ability to survive and succeed in such adverse conditions combining long dry periods and increasing human activities. In particular it is recognised that the acacia's ability to utilise dormancy as a means of avoiding climatic stress is of great importance in allowing the colonization of habitats unfavourable for growth at certain times of the year (MAHMOUD 1977). In addition, the performance and vigour of acacia trees, as indicated by the density and size of individuals, is known to differ according to the type of habitat, altitude, relative ground water content in dry periods, and human activities (MAHMOUd 1977, BATANOUNy 1987, FetENE 2003). Moreover, acacias are able to increase as the main encroacher in overgrazed habitats due to their large shallow lateral roots. ToLSMA et al. (1987) and SKARPE (1990) attribute the success of shallow-rooted acacias as compared to deep rooted species in encroaching overgrazed areas to their better access to nutrients, including nitrogen fixation by Rhizobium. This is probably of particular significance in a nutrient poor environment, such as a wadi-bed, but access to water is likely to be at least as important. Therefore, the increase of Acacia spp. in the cloud forest may give a good indication of the progress of wider vegetation changes that occur in the disturbed sites of this forest, from a wet closed forest habitat to more open dry savanna conditions. This steady replacement of the common and endemic woody trees and shrubs typical of the wet cloud forest is well illustrated by the case of Anogeissus dhofarica (a closed canopy species) which exhibited a J-shaped distribution towards larger individuals in all habitats of the wadi, tending to indicate a declining population with limited regeneration capacity or higher mortality of young individuals. (NARUKAWA and YAMAMOTO 2002, EL-SHEIKH 2005, COOMES and Allen 2007, TANAKA et al. 2008).

In conclusion, most of the studied woody trees and shrubs in the cloud forest, especially in the wadi-bed site, have been facing many stresses from human activities in southern Oman during the past 40 years, due to modernization and road construction inside this natural cloud forest. Some of these studied populations are the endemic species Anogeissus dhofarica, Maytenus dhofariensis, Ormocarpum dhofarense and it is these that are considered to be among the most threatened species in the cloud forest of Dhofar region due to their widespread collection for fodder, medicine, buildings and firewood (MILLER and Morris 1988, GHAZANFAR 1998, BRINKMANN et al. 2009). In general, different types of human impacts, mainly obvious, cause degradation in the cloud forest in Wadi Garziz. The size structure frequencies of these woody species give a good indication of the vegetation changes consequent to this human activity and further indicate that these are occurring especially in the wadi-bed, which seems to be experiencing a greater level of disturbance than the hill-slope areas, with a number of threatened species. This information on species distributions and threats is important for formulating management plans, and the size-class assessment method can be recommended for use in disturbed environments where changes are occurring quickly and where environmental management plans are therefore needed urgently. 


\section{Acknowledgements}

I would thank Prof. Loutfy Boulos Botany Department, Faculty of Science, Alexandria University, Prof. K. H. Shaltout, Botany Department, Faculty of Science, Tanta University and Prof. A. K. Hegazy, Botany and Microbiology Department, College of Science, King Saud University for valuable comments. I also thank Distinguished Scientist Fellowship Program of King Saud University and Mr Karl Woodgett for assistance in proof reading a draft of this article.

\section{References}

Agren, J., ZaCKRISSON, O., 1990: Age and size structure of Pinus sylverstris populations on mires in central and northern Sweden. Journal of Ecology 78, 1049-1062.

Al-SodAnY, Y. M., 2003: Size structure and dynamics of the common shrubs in Omayed Biosphere Reserve in the western Mediterranean coast of Egypt. Ecologia Mediterranea 29, 39-48.

ANONYMOUS, 1983: Ecosystem forestiers tropicaux d'Afrique. ORSTOM-UNESCO, Paris.

AnONymous, 2004: Water resources in Sultanate of Oman. Ministry of Regional Municipalities, Environment and Water resources, Muscut, Sultanate of Oman.

Batanouny, K. H., 1987. Current knowledge of plant ecology in the Arab Gulf countries. Catena 14, 291-316.

BAXTER, W. J., GetZ, M., WAYne, P., 2005: A model-farmed evaluation of elephant effects on tree, fire dynamics in Africa savannas. Ecological Application 154, 1331-1341.

Briggs, J. M., SchaAfsma, H. D., Trenkov, D., 2007: Woody vegetation expansion in a desert grassland: Prehistoric human impact? Journal of Arid Environments 69, 458-472.

Brinkmann, K., Pazelt, A., Dickhoefer, U., Schlecht, E., Buerkert, A., 2009: Vegetation patterns and diversity along an altitudinal and grazing gradient in the Jabal al Akhdar mountain range of northern Oman. Journal of Arid Environments 73, 1035-1045.

CAsswell, H., 1986: Life cycle models for plants. Lectures on Mathematics in the Life Sciences 18, 171-233.

Coomes, D. A., Allen, R. B., 2007: Mortality and tree size distributions in natural mixed-age forests. Journal of Ecology 95, 27-40.

CRISP, M. D., LANGE, R. T., 1976: Age structure, distribution and survival under grazing of the arid-zone shrub Acacia burkitii. Oikos 27, 86-92.

DANSEREAU, P., LEMS, K., 1957: The grading of dispersal types in plant communities and their ecological significance. Contributions de L'Institute Botanique Institute of Botany, University of Montreal 71, 1-52.

EL-BAz, F., 2002: Wadis of Oman satellite image atlas. Center for Remote Sensing, Boston University; Office of the Advisor to His Majesty the Sultan for Cultural Affairs Publishing, Muscut, Sultanate of Oman.

EL-SheIKH, M. A., 2005: Plant succession on abandoned fields after 25 years of shifting cultivation in Assuit, Egypt. Journal of Arid Environments 61, 461-481.

FETENE, M., 2003: Intra-and inter-specific composition between seedlings of Acacia etbaica and a perennial grass (Hyparrenia hirta). Journal of Arid Environments 55, 441-451. 
Fisher, M., GARDNER, A., 1995: The status and ecology of a Juniperus excelsa subsp. polycarpos woodland in the northern mountains of Oman. Vegetatio 119, 33-51.

GHAZANFAR, S., 1998: Status of the flora and plant conservation in the Sultanate of Oman. Biological Conservation 85, 287-295.

GoldBerG, D. E., Turner, R. M., 1986: Vegetation change and plant demography in permanent plots in the Sonoran desert. Ecology 67, 695-712.

GrAY, B., 1975: Size-composition and regeneration of Araucaria stands in New Guinea. Journal of Ecology 63, 273-289.

GreEn, D. F., Johnson, E. A., 1996: Wind dispersal of seeds from a forest into a clearing. Ecology 82, 595-609.

GRIME, J. P., 1979: Plant strategies and vegetation processes. Wiley, New York.

HALL, P., BAWA, K., 1993: Methods to assess the impact of extraction of non-timber tropical forest products on plant populations. Economic Botany 47, 234-247.

Harper, J. L., White, J., 1974: The demography of plants. Annual Review of Ecology Evolution and Systematics 5, 419-463.

HARPER, J. L., 1977: Population biology of plants. Academic Press, London.

Hildebrandt, A., Eltahir, E. A. B., 2006: Forest on the edge: Seasonal cloud forest in Oman creates its own ecological niche. Geophysical Research Letter 33, L11401.

Hildebrandt, A., Al Aufi, M., Amerjeed, M., Shammas, M., Eltahir, E. A. B., 2007. Ecohydrology of a seasonal cloud forest in Dhofar: 1. Field experiment. Water Resources Research 43, W10411.

Hou, J. H, Mi, X. C., LiU, C. R., MA, K. P., 2004: Spatial patterns and associations in a Quercus-Betula forest in North China. Journal of Vegetation Science 15, 407-414.

Huston, M., 1986: Size bimodality in plant populations: an alternative hypothesis. Ecology 67, 265-269.

LYKKE, A. M., 1998: Assessment of species composition change in savanna vegetation by means of woody plant's size class distributions and local information. Biodiversity and Conservation 7, 1261-1275.

Mahmoud, A., 1977: Germination of three desert Acacias in relation to their survival in arid environment. Proceedings 1 Conference of Saudi Biological Society, Riyadh, 47-94.

Manabe, T., Nishimura, N., Miura, M., Yamamoto, S., 2000: Population structure and spatial patterns for trees in a temperate old-growth evergreen broad-leaved forest in Japan. Plant Ecology 151, 181-197.

Masaki, T., Suzuki, W., Niryama, K., Iida, S., Tanaka, H., Nakashizuka, T., 1992: Community structure of a species rich temperate forest, Ogawa Forest Reserve, central Japan. Vegetatio 98, 97-111.

Miller, A. G., Morris, M., 1988: Plants of Dhofar, the southern region of Oman: Traditional, Economic and Medicinal uses. Office of the Adviser for Conservation of the Environment, Diwan of Royal Court Sultanate of Oman Publishing, Sultanate of Oman.

Miller, G. M., 1994: Dhofar Fog Oasis, Oman and Yemen. In: Davis, S. D., HeYwood, V. H., Hamilton, A. C. (Eds.), Centres of plant diversity, 1, 309-311. World Wildlife Fund, International Union for Conservation of Nature, Gland. 
Newbery, D. McC., Gartlan, J. S., 1996: A structural analysis of rain forest at Korup and Douala-Edea, Cameroon. Proceedings of the Royal Society of Edinburgh 104B, 177224.

Nishimura, T. B., Kohyama, T., 2002: Formation and maintenance of community boundaries in a sub-alpine forest landscape in northern Japan. Journal of Vegetation Science13, $555-564$.

NARUKAWA, Y., Yамамото, S., 2002: Effects of dwarf bamboo (Sasa sp.) and forest floor microsites on conifer seedling recruitment in a subalpine forest, Japan. Forest Ecology and Management 163, 61-70.

OLIVER, C. D., 1980: Forest development in North America following major disturbances. Forest Ecology and Management 3, 153-168.

Poorter, L., Bongers, F., van Rompaey, R. S. A. R., De Klerk, M., 1996: Regeneration of canopy tree species at five sites in west African moist forest. Forest Ecology and Management 84, 61-69.

Pelissier, R., GoREAUd, F., 2001: A practical approach to the study of spatial structure in simple cases of heterogeneous vegetation. Journal of Vegetation Science 12, 99-108.

RICHARD, B., DANIEL, M., 2004: Advances in spatial, individual-based modeling of forest dynamics. Journal of Vegetation Science 15, 831-842.

RAdCliffe-Smith, A., 1980: The vegetation of Dhofar. in: Scientific Results of the Oman Flora and Fauna survey 1977 (Dhofar). The Journal of Oman Studies, Special Issue 2, 59-86.

Sale, J. B., 1980: The environment of the mountain region of Dhofar. Scientific results of the Oman flora and fauna survey 1977 (Dhofar). The Journal of Oman Studies 2, 17-23.

SAKIO, H., 1997: Effects of natural disturbance on the regeneration of riparian forests in a Chichibu Mountains, central Japan. Plant Ecology 132, 181-195.

Sakio, H., Kubo, M., Shimano, K., Ohno, K., 2002: Coexistence of three canopy tree species in a riparian forest in the Chichibu Mountains, central Japan. Folia Geobotanica $37,45-61$.

Shaltout, K. H., AyYAD, M. A., 1988: Structure and standing crop of Egyptian Thymelaea hirsuta populations. Vegetatio 47, 137-142.

Shaltout, K. H., MAdy, M. A., 1993: Current situation of the raudha's woody plant populations in the Central Saudi Arabia. Feddes Repertorium 104, 503-509.

Shaltout, K. H., Sheded, M. G., El-Kady, H. F., Al-Sodany, Y. M., 2003: Phytosociology and size structure of Nitraria retusa along the Egyptian Red Sea coast. Journal of Arid Environments 53, 331-345.

Shaltout, K, Sheded, M. G., SAlem, A. H., 2009: Population structure of common shrubs and trees in Wadi Allaqi Biosphere Reserve, South-East Egypt. Feddes Repertorium $120,343-354$.

Sheded, M. G. Pulford, I. D., Hamed, A. I., 2006: Presence of major and trace elements in seven medicinal plants growing in the South Eastern Desert, Egypt. Journal of Arid Environments 66, 210-217.

SKARPE, C., 1990: Structure of woody vegetation in disturbed and undisturbed arid savanna, Botswana. Vegetatio 78, 11-18. 
Stewart, G. H., Rose, A. B., 1990: The significance of life history strategies in the development history of mixed beech (Nothofagus) forests, New Zealand. Vegetatio 87, 101-114.

Stohlgren, T. J., Backand, R. R., OnAmi, Y., Binkley, D., 1998: Species-environment relationships and vegetation patterns: effects of spatial scale and tree life-stage. Plant Ecology 135, 215-229.

TAKAHASHI, K., 1994: Effect of size structure, forest floor type and disturbance regime on tree species composition in a coniferous forest in Japan, Journal of Ecology 82, 769-773.

Takahashi, K. Homma, K., Vetrova, V. B., Florenzev, S., Hara, T., 2001: Stand structure and regeneration in a Kamchatka mixed boreal forest. Journal of Vegetation Science 12, $627-634$.

Tanaka, H., Shibata, M., Masaki, T., Iida, S., Nityama, K., Abe, S., Kominami, Y., NaKaSHIZUKA, T., 2008: Comparative demography of three coexisting Acer species in gaps and under closed canopy. Journal of Vegetation Science 19, 127-138.

Tolsma, D. L., ERnst, W. H. O., VerweiJ, R. A., VooiJst, R., 1987: Seasonal variation of nutrient concentrations in a semi-arid savanna ecosystem in Botswana. Journal of Ecology 75, 755-770.

Veblen, T. T., 1992: Regeneration dynamics. In: Glenn-Lewin, D. C. Peet, R. K., Veblen, T. T. (eds), Plant succession: theory and prediction, 152-187. Chapman and Hill, London.

WANG, W., MA, K. P., LiU, C. R., 1999: Removal and predation of Quercus Liaotungensis acorns by animals. Ecological Research 14, 225-232.

Wang, W., MA, K. P., LIU, C. R., 2000: Seed shadow of Quercus Liaotungensis Koidz. in a broad-leaved deciduous forest in Dongling Mountain. Acta Botanica Sinica 42, 195202.

Werner, P. A., CAsswell, H., 1977: Population growth rates vs. stage distribution models for teasel (Dipsacus sylvestris Huds.). Ecology 58, 1103-1111.

WeINER, J., 1985: Size hierarchies in experimental populations of annual plants. Ecology 66, 746-752.

WeINER, J., 1986: How competition for light and nutrients affects size variability in Ipomoea tricolor populations. Ecology 67, 1425-1427.

Welden, C. W, Hewett, S. W., Hubbell, P. S., Foster, R. B., 1991: Sapling survival, growth, and recruitment: relationship to canopy height in a neotropical forest. Ecology $72,35-50$.

Weissenhofer, M. A., 2005: Structure and vegetation dynamics of four selected one hectare forest plots in the lowland rain forests of the Piedras Blancas National Park, Costa Rica, with notes on the vegetation diversity of the Golfo Dulce region. Ph.D. Thesis, University of Wienna.

Wilson, J. B., Agnew, A. D. Q., 1992: Positive-feedback switches in plant communities. Advances in Ecological Research 23, 263-336. 